\title{
Looking for Work: Solicitation by Labor Board Employees
}

\author{
Lorraine A. Schmall†
}

This Article provides a comprehensive survey of cases where improper "solicitation" of charges by National Labor Relations Board agents has been alleged as a defense by Respondents in those cases. The Board is empowered only to act on charges brought before it by individuals, labor organizations, or employers. The author shows that the Board is without authority-either by statute, by its own rules and regulations, or from the courts-to engage in "solicitation," which includes initiating charges, filing complaints which are beyond the scope of the original charge, or acting upon events which happened greater than six months previous to the filing of the original charge. The author finds, however, that in nearly fifty years of attempts by Respondents to prove such wrongdoings, the Board has never found its agents to have overstepped their authority by engaging in acts of improper solicitation. The author proposes the framework of a test to determine when Board agents have acted excessively.

Since it began operation as an administrative agency following congressional approval of the Wagner Act in 1935, the purposes, practices, and procedures of the National Labor Relations Board have generated considerable debate. In 1938, in an editorial evaluation of the nascent Labor Board, it was written:

Employers ought to refuse to have anything to do with the National Labor Relations Board. They ought to fight it out even if they have to go to jail. Fight it out as one of the fundamental principles of American liberty. ${ }^{\prime}$

Complaints about the Board are just as passionate and frequent almost five decades later. The tenor may have changed: the Taft-Hartley amendments of 1947 make labor organizations as well as employers subject to charges of unfair labor practices. Consequently, labor organizations, when named as respondents in Board cases, are as likely to allege procedural improprieties as are employers. Charges that the Board is politicized have been levied since its inception. Currently, with the growth of right-to-work sentiment, the unions claim that the Board is

$\dagger$ Adjunct Professor of Law, Chicago-Kent College of Law. Associate, Baum and Sigman, Ltd.; B.A., University of Illinois, Chicago Circle, 1971; M.A., Teachers College, Columbia University, 1974; J.D., George Washington University, 1981; Harry Bigelow Fellow, University of Chicago, 1983-84.

1. Lewiston (Maine) Sun, February 4, 1938, editorial cited in Gellhorn \& Linfield, Politics and Labor Relations: N.L.R.B. Procedure, 39 Colum. L. REv. 339 (1939). 
unfairly refusing to process their charges or protect their interests. In other times-during periods of union strength-similar complaints were raised by employers.

Ironically, another allegation, raised by both sides in the labor-management struggle at various times, is that the Board will not leave them alone. Both sides have frequently, but never successfully, claimed that Board agents are guilty of soliciting the filing or amendment of an unfair labor practice charge, or of initiating or amending a complaint that is not properly grounded upon the timely-filed allegations of a charging party. Such practices apparently contravene Board policy.

The Labor Board, unlike some other agencies, has no "carte blanche" to find violators and bring them to justice. The Wagner Act, which created the Board, originally provided that the Board could act "whenever there is a charge or the Labor Board shall have reason to believe" that an unfair labor practice was committed. ${ }^{2}$ When the bill was reported out of committee in 1935, however, the "reason to believe" language was deleted and the present language "whenever it is charged" was substituted therefor. ${ }^{3}$ The change in language, however, has not restrained the Board from protecting the rights of employers and employees even if uninvited to do so.

Supposedly, only the filing of a charge by a person outside the Board can "provide the spark which starts the machinery of the Act running." 4 It is succinctly stated in the manual provided employees of the Board: "To the end that appropriate action consistent with the Act will eventually be taken, the filing of a charge is a condition precedent to and initiates the investigation of an unfair labor practice."5 In a dissenting opinion in NLRB v. Nash-Finch Co., Justice White explained:

[T] he Board is not granted unqualified powers to enforce the Act. The statute conditions Board action against unfair labor practices upon the filing of a charge; it may not act on its own motion . . . . The Board has no roving, unqualified power to prevent unfair labor practices or to enforce the provision of $\S 7$ [of the Act] declaring that employees shall have the right to organize, bargain collectively, and otherwise engage in concerted activities. ${ }^{6}$

But review of nearly fifty years of litigation before the Labor Board reveals a stark, yet undeniable, fact: the Board does indeed have unqualified though unauthorized power to right the wrongs that are, in whatever

2. S. ReP. No. 1958, 74th Cong., 1st Sess. (1935), reprinted in 1 Legislative History of the NATIONAL Labor Relations ACt, at 1301 (1935).

3. S. Rep. No. 1958, 74th Cong., 1st Sess. (1935), reprinted in 2 Legislative History of THE NATIONAl LABOR Relations Act, at 2292 (1935).

4. Cusano v. NLRB, 190 F.2d 898, 903 n.8 (3rd Cir. 1951).

5. NLRB Casehanding Manual, pt. $1, \S 10010$ (1983) [hereinafter cited as CaSehaNdLing MANUAL].

6. 404 U.S. 138, 151.52 (1971) (White, J., dissenting). 
fashion, brought to its attention. In case after case, tribunals at all but the highest level of appeal have either refused to deal with the issue of solicitation or, by mindlessly citing to earlier cases in which the accusation was found to have no merit, have perfunctorily dismissed it.

\section{I}

\section{A Problem Defining the Problem}

The appropriate definition of solicitation or improper initiation is largely an academic question, since the Board has never found its agents guilty of such a misdeed. Respondents' attempts to define the problem generally fall into one of three categories: 1) actual solicitation, where an agent of the Board solicits a charge or an amendment which would not otherwise have been filed; 2) consideration of time-barred acts, where the Board improperly considers alleged illegal acts on the part of respondents occurring outside the six-month statute of limitations period in the Act; 3) issuance of a complaint unrelated to the charge, where an agent of the Board improperly initiates an amendment or complaint that has no basis in the original charge filed by the charging party. ${ }^{7}$

In the absence of any statutory definitions ${ }^{8}$, one must rely upon op-

7. 29 U.S.C. $\$ 160(b)(1982)$.

8. A limitation on the Board's power is nowhere specifically stated in the National Labor Relations Act. Rather, it is extrapolated from various provisions in the Act, Board Rules and Regulations and Statements of Procedure, and the Casehandling Manual written for Board employees. Section 10(b) of the Act provides:

Whenever it is charged that any person has engaged in or is engaging in any such unfair labor practice, the Board, or any agent or agency designated by the Board for such purposes, shall have power to issue and cause to be served upon such person a complaint stating the charges in that respect, and containing a notice of hearing before the Board or member thereof. . . . Provided that, no complaint shall issue based upon any unfair labor practice occurring more than six months prior to the filing of the charge with the Board and the service of a copy thereof upon the person against whom such charge is made. Any such complaint may be amended by the member, agent, or agency conducting the hearing, or the Board in its discretion at any time prior to the issuance of an order based thereon. The person so complained of such have the right to file an answer to the original or amended complaint.

Id. The Board's own rules provide that "a Charge that a person has engaged or is engaging in any unfair labor practice affecting commerce may be made by any person." N.L.R.B. Rules and Regulations and Statements of Procedure, 29 C.F.R. $\$ 102.9$ (1984). Numerous provisions in the Casehandling Manual reinforce the position that the impetus for filing a charge must come from the Charging Party, not from a Board agent.

Neither the Act nor the Rules and Regulations offer much detail on the filing of a charge. The Casehandling Manual, however, provides more specific, although not totally unambiguous, procedural guidelines. A section entitled, "information as Contrasted with Advice," provides fodder for respondents who assert that a Board agent who goes beyond a quasi-ministerial posture in the taking of charges is guilty of solicitation. The rather lengthy section of the Manual provides in pertinent part:

$[R]$ equests for information may be honored only to the extent that they seek information, as contrasted with advice, concerning rights, obligations, and general contents of the Act. Answers should be succinct, and they must include all reservations which are necessary in a field as fluid as the area covered by the Act. . . . Regional personnel should not give advisory opinions as to the "legality" of given conduct or contract clauses. 
erational definitions. These, unfortunately, are as varied as the parties and the issues in any Board proceeding. Examination of case law provides these examples of the first form of solicitation, what I refer to as actual solicitation: 1) during investigation of a charge, a Board agent advised two witnesses for Charging Party that they may themselves have a charge and be eligible for back pay; ${ }^{9}$ 2) a Board attorney induced a person to sign a charge without telling him he was actually initiating an unfair labor practice charge against his employer; ${ }^{10} 3$ ) a Board agent solicited a second charge against the employer from a Charging Party who had already filed a charge against his union; ${ }^{11}$ 4) a Board agent solicited a second charge against the union from Charging Party who had already filed against his employer; ${ }^{12}$ ) a Board agent gave a Charging Party information uncovered during an investigation of an earlier section 8(b) charge in order to properly amend a new section 8(a) charge to add a second respondent as a "single employer"; ${ }^{13}$ 6) a Regional Director dismissed a section $8(a)(3)$ allegation that Charging Party was illegally fired, but, relying on pre-printed boiler-plate allegations that the employer had engaged in unfair labor practices within the meaning of section $8(a)(1)$, advised Charging Party that he would issue a complaint on the section $8(\mathrm{a})$ (1) allegations-even though the Charging Party never alleged any specific section $8(a)(1)$ violations; ${ }^{14}$ 7) while investigating alleged violations of sections 8(a)(1), (2), and (3), based upon the closing of Respondent's plants for several hours, a Board field examiner suggested amendments alleging the illegal discharge of employees three months prior to the plant closings. ${ }^{15}$

The second form of solicitation, and the type most commonly alleged by Respondents, is where, either through issuance of complaints ${ }^{16}$

Casehandling Manual, supra note 5 , at $\S 10012.5$.

A later provision explains to the Board agent that "[a]ssistance in the preparation of a charge may be rendered to the filing party to the extent that such assistance involves the furnishing of forms, reasonable clerical/stenographic assistance, and wording of the charge itself." Id. at $\S 10012.6$. But, in apparent contradiction of these severe limits on the Board agent's role, the same manual provides detailed procedures on investigation and follow-up assistance to the charging party. "[I]n general . . . [the investigation] must . . . reveal the entire picture. . .," even to the extent that the investigating agent can "notify the Charging Party (or attorney of record) of the facts and of a potential deficiency" of the original charge. Id. at $\S 10064.5$.

9. Capitol Fish Co., 140 N.L.R.B. 837, 850-51 (1963).

10. The Great Atl. and Pac. Tea Co., 145 N.L.R.B. 361, 385-88 (1963), enforced in part, 340 F.2d 690 (2nd Cir. 1965).

11. Parisian Bakeries, 169 N.L.R.B. 1047 (1968).

12. Swier Elec. Co., 223 N.L.R.B. 569, 572-73 (1975).

13. Tabernacle Sand and Gravel Corp., 232 N.L.R.B. 957, 960-61 (1977).

14. Red Food Stores, 252 N.L.R.B. 116 (1980). Accord Pennco, Inc., 212 N.L.R.B. 677, 67879 (1974).

15. NLRB v. Reliance Steel Prods., 322 F.2d 49, 53 (5th Cir. 1963).

16. This refers to a formal complaint, which is issued when the General Counsel of the Board after investigation by Board agents has reason to believe that violations have occurred, as distinct from a charge, which is the allegation filed by the charging party to initiate an investigation. 
or complaint amendments, the Board considers alleged illegal acts which should be barred under the National Labor Relations Act charge-filing time limitation of six months. Case law provides the following examples of this second form of solicitation: 1) a complaint was amended to name a second Respondent who was found to be the alter-ego of the firstnamed Respondent in Charging Party's original allegations, although the alleged illegal activity by the second Respondent occurred more than six months prior to the filing of the charge; ${ }^{17}$ 2) a charge against a union that alleged "certain employees" were coerced into paying initiation fees and dues under threat of being discharged from their employment was amended six months later by adding the names of these certain employees; ${ }^{18}$ 3) names of alleged discriminatees were added or deleted more than six months after their allegedly illegal terminations; ${ }^{19}$ 4) an amendment to a charge added the names of certain employees whom the employer had failed to reinstate after a strike, even though this failure occurred more than six months prior to the date of the filing of the charge; ${ }^{20}$ 5) a Charging Party, who had alleged that a union violated section $8(\mathrm{~b})(1)(B)$, amended that charge three months later, alleging the illegal suspension of two supervisors which had occurred more than six months prior to the date of the filing of the charge; ${ }^{21} 6$ ) an amendment to a charge, which alleged that four employees were laid off because of their protected concerted activities, added a fifth "constructive discharge" of an employee who lost his job more than eleven months prior to the amendment; ${ }^{22}$ 7) a union filed charges alleging section 8(a)(1) and (3) violations, and one year later, after a complaint was issued, it alleged violations of section $8(\mathrm{a})(5)$, including some that occurred more than six months prior to the filing of the original charge. ${ }^{23}$

Distinct from actual solicitation, but related in tenor, is the third form of solicitation, where the charge originally filed is not broad enough to support the complaints or complaint amendments initiated by Board agents. Again, without statutory definitions ${ }^{24}$, operational definitions

17. Tabernacle Sand and Gravel Corp., 232 N.L.R.B. at 959-60.

18. Local 404, Int'l Bhd. of Teamsters, 100 N.L.R.B. 801 (1952), enforced, 205 F.2d 99 (1st Cir. 1953).

19. Daniel Constr. Co., 244 N.L.R.B. 704, 705 (1979).

20. Harris-Teeter Supermarkets, 242 N.L.R.B. 132, 154 (1979), enforced without opinion, Local 525, Meat, Food, and Allied Workers Union v. NLRB, 644 F.2d 39 (D.C. Cir. 1981).

21. New York Newspaper Pressmen's Union, 249 N.L.R.B. 1284, 1289-90 (1980).

22. Washington Beef Producers, Inc., 264 N.L.R.B. 1163, 1172 (1982).

23. Herald Co., 181 N.L.R.B. 421, 421-22 (1970), enforced, 444 F.2d 430 (2d Cir.), cert. denied, 404 U.S. 990 (1971).

24. The Act makes no provision for amending a charge, but the Board and the courts have recognized the propriety of such amendments. Brown Equip. and Mfg. Co., 100 N.L.R.B. 801 (1952), enforced NLRB v. International Bhd. of Teamsters, 205 F.2d 99 (1st Cir. 1953). The Act and the Rules and Regulations provide that generally the complaint may be amended by the Regional Director, by the administrative law judge, or by the Board any time prior to issuance of an 


\section{must suffice: 1) a Charging Party alleged the discriminatory layoff of}

order by the Board. 29 U.S.C. $\$ \$ 151-169$ (1982); 29 C.F.R. $\$ 102.17$ (1984). The rules do not treat the amendment of a charge; the only description of such procedure is in the Casehandling Manual.

There remains a question of whether the rules and the manuals are binding upon the Board. Administrative law judges, for the most part, feel bound by the rules. For example, in one case the trial examiner (and later Chief Judge for the Board) concluded that a case must be dismissed in compliance with a Board rule, since the parties had reached a voluntary agreement. He wrote:

To hold otherwise would be contrary to the spirit, if not the letter, of the Administrative Procedure Act, which provides that each Federal agency shall publish in the Federal Register its organizational, procedural, and substantive rules. . . . In addition, it is well established under court decisions that administrative rules and regulations have the force of law, are binding on the agency concerned, and their non-observance invalidates an entire proceeding.

Wood, Wire and Metal Lathers Int'1 Union, 119 N.L.R.B. 1345, 1349-50 (1958). Fifth Circuit Judge Jones found that Respondents had to comply with the Board's requirement that a contract be reduced to writing, and concluded: "It does not appear illogical to require any party . . . to adhere to the rules . . promulgated by the Board for the purpose of encouraging the desirable objective of stability and finality." NLRB v. Reliance Steel Prods., 322 F.2d at 55. Fifteen years later, the same circuit held that the Board was bound by the procedure in its own Casehandling Manual regarding refiling withdrawn charges, and that failure to comply would render its decision invalid. NLRB v. Gulf State Mfg., 579 F.2d 1298, 1308-09 (5th Cir. 1978).

But, since very early in its history, the majority of the courts of appeal has allowed the Board to deviate from its rules, in cases that have yet to be overruled. According to the Sixth Circuit, "the provisions of Article II, $\S 4$, of the Board's rules and regulations, are for the information of the Board." NLRB v. Consumers Power Co., 113 F.2d 38, 42 (6th Cir. 1940). The Ninth Circuit determined "that since the Board has the power to make the rules it has the power to suspend them." NLRB v. Pacific Gas and Elec., 118 F.2d 780, 789 (9th Cir. 1941). And the Eighth Circuit found that the pertinent rule in the case was one "which the Board in its discretion may apply or waive as the facts of a given case may demand in the interest of stability and fairness" since "the Board is not the slave of its rules." NLRB v. Grace Co., 184 F.2d 126, 129 (8th Cir. 1950). The Board's contract-bar rules were not held to preclude an election and the Seventh Circuit agreed that those rules "are solely of the Board's creation and we see no reason why the Board cannot reasonably expand or restrict this policy as it sees fit." Kearney and Trecker Corp. v. NLRB, 210 F.2d 852, 857 (7th Cir. 1954), cert. denied, 348 U.S. 824 (1954).

Many reviewing courts prefer to allow the Board to decide whether and when its rules apply. Sears Roebuck and Co. v. Solien, 450 F.2d 353, 356 (8th Cir. 1971), cert. denied, 405 U.S. 996 (1972). On those occasions where the Board has considered its own rules, it has required only "substantial conformity" therewith, International Ladies Garment Workers Union, 136 N.L.R.B. 524,530 (1962), and has concluded that: "[t]he Board's rules relative to the contents of a charge are primarily for the benefit of the Board-to aid it in the performance of its administrative and investigative functions at the 'charge' stage — and cannot be interpreted as imposing the equivalent of statutory jurisdictional limitations." The Singer Co., Wood Prods. Div., 158 N.L.R.B. 677, 680 n.3 (1966). The purport of these decisions in the area of solicitation is simply that respondents cannot base their claims solely upon a violation of Board rules.

Questions as to the effect of the employee manuals, which contain the only reference to the amendment of a charge, are even harder to answer. Board employees regard them as recommended rather than mandatory procedures. The introduction to the Pleadings Manual explains: "The matters contained herein are not General Counsel or Board rulings or directives and are not a form of authority binding upon the General Counsel or upon the Board." OfFice of THE GENERAL CounSel, Operations Management, NLRB Pleadings Manual, at ii (1979). Respondents in one case sought access to the Casehandling Manual and a manual issued to Board agents entitled $A$ Guide to the Conduct of Elections. The former was handed over, but the latter was not because the administrative law judge concluded that: "The booklet in question is not within the category of those 'administrative staff manuals and instructions to staff that affect a member of the public' which must be made available under the Public Information Act of 1966." Polymers, Inc., 170 N.L.R.B. 333, 335 (1968), enforced, 414 F.2d 999 (2d Cir. 1969), cert. denied, 396 U.S. 1010 (1970). The judge 
certain employees because of union activities, including in the charge a boiler-plate allegation of section $8(a)(1)$ violations ("by these and other acts, the above-named employer did interfere with, restrain, and coerce its employees in the exercise of their rights guaranteed in section 7 of the Act"); upon investigation, the Regional Director issued a complaint alleging that the employer violated section $8(\mathrm{a})(1)$ by threatening layoffs and changed conditions with the arrival of the union, although such threats had not been alleged by the Charging Party ${ }^{25}$; 2) while the Charging Party alleged violations of sections $8(a)(1)$ and (5) due to the employer's promises of wage increases to employees who eschewed the union and the employer's refusal to bargain, the complaint issued alleged instead that the employer participated in the formation of an in-house labor organization (if proved, a violation of section $8(a)(2)$ ) without alleging violations of section $8(a)(2)$; the administrative law judge permitted a complaint amendment, alleging a violation of section $8(\mathrm{a})(2)$, more than six months after the activity actually occurred. ${ }^{26}$; 3) another original charge alleged only boiler-plate section $8(a)(1)$ language; the charge was amended one month later to allege interrogation and threats, eight months later the charge was amended to complain of illegal wage increases. $^{27}$; 4) a Charging Party's allegation that his union forced his company to discriminate against him led to a Board complaint that included a claim that the union imposed a fine upon the Charging Party after his membership expired ${ }^{28}$; 5) amendments to charges and/or complaints to add or delete names of discriminatees or alleged wrongdoers are frequently complained of. ${ }^{29}$

\section{II}

\section{Testimonial Privilege of BoArd Agents}

Solicitation and improper initiation remain factually undefined be-

further found that the "procedures described in the document were not intended to be all-inclusive or of mandatory effect." Id.

Moreover, the instructions in the manuals are themselves inconsistent. Board employees are advised that "assistance to the extent permitted in connection with original charges may be rendered in connection with the filing of such amendments," CASEHANDling MANUAL, supra note 5, at $\S 10064.3$, that is, "information, as contrasted with advice . . . [or] advisory opinions." Id. at $\S 10012.5$. But after investigation of any charge, agency personnel are exhorted to "notify the Charging Party (or attorney of record) of the facts and of a potential deficiency" of the original charge, and the Charging Party "should be apprised of the effect of the suggested amendment as well as the effect of the failure to amend. . . ." (Emphasis added.) Id. at $\S 10064.5$. Thus each Board agent must decide at what point "apprising" of an effect becomes a prohibited "advisory" recommendation to amend.

25. NLRB v. Kohler Co., 220 F.2d 3, 7 (7th Cir. 1955).

26. Sunrise Manor Nursing Home, 199 N.L.R.B. 1120 (1972).

27. Marines Memorial Club, 261 N.L.R.B. 1357, 1365 (1982).

28. NLRB v. American Bakery \& Confectionary Workers Union, Local 300, 411 F.2d 1122, 1125-26 (7th Cir. 1969).

29. See, e.g., Local 404, Int'l Bhd. of Teamsters, 100 N.L.R.B. 801 (1952). 
cause no case has ever found either of them. Twenty-four years ago, however, in Petersen Construction Corp., the Board did determine that the issue of solicitation was litigable. ${ }^{30}$ Respondents in that case alleged that amended charges adding an employer association and twenty unions, all signatories to a single contract, as Respondents, were invalid because the regional Board personnel solicited such charges. The Board examined Respondents' allegations, although it ultimately found no merit in them. Then-Chairman Leedom of the Board, however, dissented from the finding on the merits of the solicitation allegations, finding improper solicitation because "the decision to add approximately twenty-four additional Respondents was made by regional personnel and was tantamount to initiating such action."31

Even though solicitation may be litigable, respondents often find that their best source of evidence on the issue-the Board agent-is shielded from scrutiny. The burden of convincing a fact-finder that solicitation or improper initiation occurred is exacerbated by section 102.118 of the NLRB Rules and Regulations (rule 102.118), which establishes a privilege against testimony or the production of documents by Board agents:

No . . . employee of the Board shall produce or present any files . . . or testify ... with respect to any information ... whether in answer to a subpoena duces tecum, or otherwise, without the written consent of the Board or the chairman of the Board . . . or the General Counsel . . . . Whenever any subpoena shall have been served upon any . . . employee of the Board, he will . . . move . . . to have such subpoena invalidated on the ground that the evidence sought is privileged against disclosure by this rule. ${ }^{32}$

In applying this rule, the ordinary procedure is that a petition to revoke a subpoena ad testificandum or a subpoena duces tecum is routinely filed by the General Counsel and is just as routinely granted by the administrative law judge. ${ }^{33}$

It is extremely rare that a Respondent can attempt to prove a Board agent solicited a charge by subjecting that agent to cross-examination. The case most frequently cited as one of those rare examples is Capitol Fish Company. ${ }^{34}$ In its original decision in Capitol Fish, the Board had approved a cease and desist order against the employer for "interrogating

30. Petersen Constr. Corp. (Hod Carriers, Local 220), 128 N.L.R.B. 969 (1960), supp. op., 134 N.L.R.B. 1768 (1961), enforced, NLRB v. Hod Carriers \& Common Laborers Union, 336 F.2d 459 (9th Cir. 1964).

31. Id. at 981 .

32. 29 C.F.R. $\$ 102.118(a)(1)(1984)$.

33. Comments of David Davidson, Assistant Chief Administrative Law Judge of the National Labor Relations Board, at the George Washington University National Law Center (November 5 , 1980).

34. 140 N.L.R.B. 837 (1963). 
its employees concerning their union activities, by creating the impression of surveillance . . . by threatening reprisals and promising benefits . . . and by discriminatorily discharging employee Benny Hill, $\mathrm{Jr}{ }{ }^{35}$ At the original hearing, Respondent alleged that the Board investigating attorney had improperly solicited "false or twisted statements" from witnesses to corroborate statements made by the Charging Parties, but this allegation was rejected by the Board. In its brief to the Fifth Circuit, to which the Board had appealed for enforcement, the Respondent argued:

[R]espondent had made a written request for permission for Mr. Miller [the Board attorney] to testify, pointing out that it had been furnished affidavits by two employees that Mr. Miller, during the investigation, accompanied by Benny Hill, one of the complaining parties, approached them and in seeking to elicit a statement said at one point during the conversation, "You guys want to help Benny, don't you?" and at another point during the conversation said, "You ought to think about him and his family because it could have been you." The General Counsel denied permission for Mr. Miller to testify. The foregoing rulings by the trial examiner were predicated upon such denials. Exceptions were taken to the rulings.

Such persuasion is the antithesis of an impartial investigation and demonstrated the need for the testimony of Mr. Miller in the interest of a fair trial so that respondent could test the credibility of the witnesses against it.

Respondent requested consent of the General Counsel for the attorney to testify as required by the Regulations, and showed good cause for the testimony, which are the prerequisites for obtaining it. ${ }^{36}$

The court held for Respondent, finding that the testimony of counsel for General Counsel was erroneously excluded, and that rule 102.118 could not, without more, preclude that attorney's cross-examination. It concluded that: "[f]undamental fairness requires that Capitol Fish be allowed to introduce testimony that may impeach the evidence offered aginst it."37 The court further held that rule 102.118 did not create an automatic privilege but that "the ultimate determination of the privilege remains with the courts." 38 The case was remanded to the Board and an administrative law judge took testimony from the investigating attorney, after which the trial examiner "recommended that all concluding findings in his [earlier] intermediate and the Board's original Decision and Order be affirmed." 39 The Board followed his recommendation, repeating its original findings against Capitol Fish.

35. Id. (citing 126 N.L.R.B. 980 (1960)). 34.

36. Brief for the Respondents, NLRB v. Capitol Fish Co., 294 F.2d 868 (5th Cir. 1961), at 32-

37. 294 F.2d at 875.

38. Id.

39. 140 N.L.R.B. 837,838 (1963). 
In another case, The Great Atlantic and Pacific Tea Company, ${ }^{40}$ rule 102.118 prompted the trial examiner to revoke the subpoena issued to the investigating attorney because the General Counsel, without specifying his reasons, refused permission for his counsel to testify. The Respondents alleged that the Board agent solicited the signature on a charge and that the Charging Party did not understand what it was he signed. The trial examiner felt "bound by the Board's rules" 41 but expressed disagreement with the effect of those rules:

The Board has held that the issue of solicitation is litigable but has refused to make available the evidence that would allow the Respondents to litigate the issue. It has, instead, permitted its General Counsel to avail himself of its rule of self-imposed and self-serving immunity without making any claim of public policy, security, or confidence or asserting any reason for his refusal other than the naked claim of its protection. ${ }^{42}$

Interestingly, the Board's only response to the probings of the trial examiner on the propriety of rule 102.118 as a means of avoiding having to disprove Respondent's allegations of solicitation by Board agents was a cryptic footnote: "[W]e expressly disavow the remarks made by the Trial Examiner about the mode and character of operations of the General Counsel and regional personnel."43

The Board's decision in Atlantic and Pacific is consistent with its decision a few months earlier in Reliance Steel Products, ${ }^{44}$ where it found that there was no prejudice to Respondent in quashing a subpoena duces tecum and refusing to allow testimony by a field examiner when Respondent sought to prove solicitation and improper Board initiation of an amendment. However, the rationale behind the Reliance decision was different. In Reliance, the trial examiner found that amendments to the original charge could not have been solicited since "those of the later date differ from the original charge only in that they are not particularized as to alleged violations of the same section of the Act."45 In enforcing the Board's cease and desist order, the Fifth Circuit determined that the sufficiency of the charge disposed of both Respondent's allegations, namely, that the Board agent solicited the charges and that rule 102.118 denied Respondent the opportunity to prove its allegations:

The precise question thus raised is not whether the complaint as finally issued was supported by the amended charges, but whether those amended charges were improperly initiated by the Board. In either case, it seems that the test to be applied to determine the question of improper Board solicitation is the same; whether the Board has gotten "so com-

40. 145 N.L.R.B. 361 (1963), modified on other grounds, 340 F.2d 690 (2nd Cir. 1965).

41. Id. at 385 .

42. Id. at 386 .

43. Id. at 363 n.3.

44. 135 N.L.R.B. 730 (1962), enforced, 322 F.2d 49 (5th Cir. 1963).

45. Id. at 736 . 
pletely outside of the situation which gave rise to the original charge that it may be said to be initiating the proceeding on its own motion. . . ." N.L.R.B. v. Kohler Company, 220 F.2d at 7 (7th Cir. 1955).

It follows that Respondent's next objection-that the Board erred in quashing the subpoena duces tecum and in refusing to allow testimony by the field examiner or presentation of the Board manual-is also without merit. Since the amendments did not exceed the scope of the original charges filed by District 50, but were supported thereby, the issue of fact concerning the source of such amendments and hence the evidence in testimony going toward proving such facts, were irrelevant to the question of the jurisdiction and the legality of its order. ${ }^{46}$

A few years later, the General Counsel, "relying solely" on rule 102.118, refused to grant his consent to a Board attorney to testify at a trial. ${ }^{47}$ Respondent wanted to question the attorney concerning notes or documents he had in his possession, for purposes of impeachment. Pursuant to the General Counsel's refusal to grant such permission, the subpoena duces tecum was revoked. Respondent then appealed to the Ninth Circuit which, although finding the administrative law judge had committed error in revoking the subpoena, affirmed and enforced the order of the Board against Respondent. According to the court, the error was not "sufficiently grave to deny enforcement."48

Rule 102.118 was invoked again in Wilmot $v$. Doyle, ${ }^{49}$ in which the General Counsel refused to allow the Board attorney to testify and produce materials concerning settlement negotiations. In an unusual move, the NLRB administrative law judge refused to revoke the subpoena duces tecum, joined the Union Respondent, and sued in a district court of equity to enforce the subpoena. The district court held for the Union. The Court of Appeals for the Ninth Circuit, however, reversed, admonishing the parties to exhaust their Board remedies, that is, to appeal to set aside the Board's final order, rather than to seek separate review of alleged procedural errors. There are, of course, almost no cases in which a Board's order was denied enforcement by a circuit court of appeals because of alleged improper solicitation.

In another case, the Eighth Circuit found that rule 102.118 did confer a privilege, albeit a narrow one. ${ }^{50}$ The court took cognizance of the Board's rationale in invoking the privilege:

[G]eneral disclosure in Board or court proceedings of all interviews and conversations between employees and investigators would compromise the investigators' appearance of impartiality and would impair the func-

46. NLRB v. Reliance Steel Prods., 322 F.2d 49, 53-54 (5th Cir. 1963).

47. NLRB v. Seine \& Line Fishermen's Union, 374 F.2d 974, 980 (9th Cir.), cert. denied sub nom. Biazevich v. NLRB, 389 U.S. 913 (1967).

48. Id. at 981 .

49. 403 F.2d 811 (9th Cir. 1968).

50. Stephens Produce Co. v. NLRB, 515 F.2d 1373 (8th Cir. 1975). 
tion of the Board in investigating, processing, and resolving unfair labor practice charges. ${ }^{51}$

The court distinguished Capitol Fish because in that case, according to the court, the Board's refusal to produce the agent was "based solely on its own internal rule." The court then found that "the instant case is different because the Board had based its refusal to allow the testimony not simply on the internal rule, but at least in part, on the established evidentiary privilege for the informal deliberations of all prosecutorial agencies and branches of the government."52 Apparently, if the General Counsel calls rule 102.118 a privilege, his or her denial of permission for Board agent testimony is accorded more respect.

In reviewing M.S.P. Industries, Inc. v. NLRB, the Tenth Circuit agreed that there was a limited privilege based on rule 102.118 , but clarified that "the mere incantation of such privilege is not conclusive . . . . And the hearing tribunal and the courts, not the adversary General Counsel, have the responsibility of deciding whether such a privilege is available."53 Nevertheless, the court affirmed the Board on the merits of the case as well as on the issue of allowing the refusal of the testimony of the Board's agent.

It appears that rule 102.118 is a barrier with which respondents must reckon, and if their only recourse in proving solicitation or improper initiation is by investigating or examining the Board agent, their chances of success are slim. The Board refuses to relax its rules concerning testimony of its agents, and respondents who are suspicious of the results of a particular investigation by a Board agent are left only to wonder about the agent's handling of his or her transition between the conflicting roles of impartial investigator and legal adversary.

III

\section{The Non-Issue of Solicitation-The Courts Review THE EARLy CASES}

When first presented with the issue of solicitation and improper initiation, the courts affirmed the Board's liberal construction of its powers. That posture, established while the Board was just beginning to wrestle with the industrial warfare nefarious employment practices common to labor relations of that time, has not been altered since those early decisions.

The Supreme Court has never directly considered the issue of solicitation of a charge by an agent of the Labor Board. In 1939, however, it acknowledged in a positive tone the Board's operating mode of subjecting

51. Id. at 1377.

52. Id. at 1376 n.l.

53. 568 F.2d 166, 178 (10th Cir. 1977). 
all of respondent's behavior to examination once a charge is filed. In National Licorice Co. v. NLRB, ${ }^{54}$ respondent argued that the Board had no jurisdiction to issue its cease and desist order because it related to unfair labor practices that were not alleged in the initial charge. The Court determined that:

It is unnecessary for us to consider now how far the statutory requirement of a charge as a condition precedent to a complaint excludes from the subsequent proceedings matters existing when the charge was filed, but not included in it. Whatever restrictions the requirements of a charge may be thought to place upon subsequent proceedings by the Board, we can find no warrant in the language or purposes of the Act for saying that it precludes the Board from dealing adequately with unfair labor practices which are related to those alleged in the charge and which grow out of them while the proceeding is pending before the Board. The violations alleged in the complaint and found by the Board were but a prolongation of the attempt to form the company union and to secure the contracts alleged in the charge. All are of the same class of violations as those set up in the charge and were continuations of them in pursuance of the same object. The Board's jurisdiction having been invoked to deal with the first steps, it had authority to deal with those which followed as a consequence of those already taken. ${ }^{55}$

It appears that the Court was loathe to limit the Board's power to investigate and eradicate any "charged" unfair labor practices, the widespread existence of which prompted the creation of the Board just a few years earlier.

When presented with a similar case twenty years later, the Supreme Court was again tolerant of the Board's actions. In NLRB v. Fant Milling Company, ${ }^{56}$ the union had filed a section 8(a)(5) charge; the Regional Director had declined to issue a complaint because he found the evidence of refusal to bargain insufficient. Later, the Respondent unilaterally granted a general wage increase and notified the union that it was refusing to recognize it and would no longer bargain with it. In the light of these additional facts, and although no amended charge was filed, the Board issued a complaint. The court of appeals denied the Board's petition for enforcement and held that section 10(b) of the Act requires that "a charge must set up facts showing an unfair labor practice. . . ."57 The Supreme Court reversed, enforcing the Board's order and upholding the complaint. According to the Court:

A charge filed with the Labor Board is not to be measured by the standards applicable to a pleading in a private law suit. Its purpose is merely to set in motion the machinery of an inquiry . . . The responsibility of

\footnotetext{
54. 309 U.S. 350 (1940).

55. Id. at 369 .

56. 360 U.S. 301 (1959).

57. 258 F.2d 851, 855 (5th Cir. 1958), rev'd, 360 U.S. 301 (1959).
} 
making that inquiry and of framing the issues in the case is one that Congress has imposed upon the Board, not the charging party. To confine the Board in its inquiry and in framing the complaint to the specific matters alleged in the charge would reduce the statutory machinery to a vehicle for the vindication of private rights. This would be alien to the basic purpose of the Act. The Board was created not to adjudicate private controversies but to advance the public interest in eliminating obstructions to interstate commerce, as this Court has recognized from the beginning. ${ }^{58}$

An allegation that the Board improperly initiated charges was first raised in the Second Circuit soon after the Board's creation, in NLRB v. Hopwood Retinning Co.. ${ }^{59}$ A respondent challenged the jurisdiction of the Board to issue a cease and desist order against it, due to the Board's failure to secure and serve upon that Respondent a complaint and notice of hearing. Although the Respondent was a proven alter-ego of the named and served Respondent, upon review, the court held in its favor, because " $[t]$ his procedure is required as a prerequisite to the jurisdiction of the Board." The court further directed that "the complaint issued and the subsequent hearing must be in accord with the charge in an attempt to prove or rebut such charges. . . . The Board cannot use its own initiative in respect to charging unfair practices."60 Such strict compliance with the charge has not been demanded by any court or reviewing Board since then, even though a close reading of section $10(\mathrm{~b})$ would suggest it. Although the requirement for proximity between charge and complaint has been greatly liberalized, Hopwood eventually stood for proof of the proposition that the Board cannot initiate an unfair labor practice.

Since then, however, reviewing courts of appeal frequently have found for the Board's General Counsel where the purposes of the Act have been, in whatever way, effectuated. When the Third Circuit held in favor of the Board in NLRB v. Weirton Steel Company in $1943,{ }^{61}$ the Board had only recently been created to combat employer unfair labor practices. Respondents had alleged numerous illegal acts by Board attorneys. The court decided that the Board should not be unnecessarily hampered since it had been legislatively granted "the power to investigate, initiate and prosecute as well as to hear and decide complaints of unfair labor practices."

Taking note of the decisions in both Fant Milling and National Licorice, in what has become the most frequently cited case concerning improper solicitation, the Seventh Circuit opined in NLRB v. Kohler:

\footnotetext{
58. 360 U.S. $301,307-08$ (1959).

59. 98 F.2d 97 (2d Cir. 1938).

60. Id. at 101 (emphasis added).

61. 135 F.2d 494 (3d Cir. 1943).

62. Id. at 497 .
} 
[S]o long as the Board entered the controversy pursuant to a formal charge, it may allege whatever it finds to be a part of the controversy. But if it gets so completely outside of the situation which gave rise to the charge that it may be said to be initiating the proceeding on its own motion, then the complaint should fall as not supported by the charge. ${ }^{63}$

In Kohler, the court upheld the Board's finding that a complaint alleging threats to employees was sufficiently close to be supported by a charge alleging only discriminatory terminations by the employer.

In an unusual decision, considering the general supportiveness of the courts on this issue, the Fifth Circuit in 1961 accused the Board, the administrative law judge, and regional Board agents of soliciting a charge in Hercules Powder Company v. NLRB. ${ }^{64}$ Both the trial examiner and the Board had found that the Respondent employer violated sections $8(a)(1)$ and (3) by curtailing production and locking out its employees while active bargaining negotiations were still in progress. Although the facts appeared to support the findings, the president of the union had not complied with section 9 of the Taft-Hartley Act, ${ }^{65}$ which required that he file an affidavit with the Board that he was not a member of the Communist Party. Without such an affidavit on file, according to the Act, "no investigation shall be made by the Board. . ., and no complaint shall be issued pursuant to a charge made by a labor organization under subsection (b) of the Act."66 The regional office had allowed the president, as an "individual", to file a charge on behalf of his membership. The regional office then mailed individual letters to the president of the local and the 109 employee members of the union advising them to report to the Board office. Before these 110 people arrived, the Board prepared, ready for the signature of each man and woman, an abbreviated generalized charge alleging similar violations of the Act by Respondent employer. Subsequently, the original charge filed by the union president was dismissed and the Board proceeded on the 110 individual charges.

The court of appeals refused to accept the trial examiner's reasoning that the union president had filed a legal charge which set the agency machinery in motion. It denied enforcement, concluding:

[T] he Board cannot have its cake and eat it too. The Board cannot assert jurisdiction, because Parsons [the president] filed a "legal charge", and at the same time assert that Parsons' filing should be disregarded because it was withdrawn. If it be considered a nulllity, the Board had no authority to engage in activities amounting to a solicitation that resulted in the Board's filing a complaint. ${ }^{67}$

63. 220 F.2d 3, 7 (7th Cir. 1955).

64. 297 F.2d 424 (5th Cir. 1961).

65. 29 U.S.C. $\S 159$ (h) (repealed at $\$ 201$ (d) of the Labor Management Reform Act of 1959, 73 Stat. 525).

66. Id.

67. 297 F.2d 424, 433 (Sth Cir. 1961). 
Despite some clear definitions of solicitation by the courts of appeal, and scattered refusals by those courts to enforce the Board's orders where extreme examples are presented ${ }^{68}$, the Board itself has never found its agents to have committed solicitation or improper initiation.

A clear example of the kind of behavior that could be considered solicitation is found in Peterson Construction Corp. ${ }^{69}$ The original charge in that case, that two local unions had caused the employer to discriminatorily discharge two individuals, was amended almost a year later, on the advice of a Board agent, to add as Respondents four employer associations and twenty local unions, all of which were signatories to a collective bargaining agreement. The Board majority found:

[T] he amended charges did not result from 'solicitation'. . . . [I]n the course of investigating the original charges, the Regional Office discovered that the discrimination against the Charging Parties had resulted from the existence and application of an unlawful contract, to which all the Respondents were parties. In these circumstances, it was the duty of the General Counsel, in discharging his responsibilities as a public official charged with enforcing public rights, to take proper measures calculated to effectively remedy all of the unfair labor practices which had been revealed by the investigation. . . . [T] he regional personnel did nothing more than furnish [Charging Party] with appropriately drawn charges and instructions to sign them if he wished to. . . . Nor does it appear significant that the initial impetus to remedy the additional unfair labor practices may have originated in the Regional Office. As the Regional Office, and not the Charging Party, conducted the investigation which uncovered the additional matters, this could hardly have occurred in any other sequence. $^{70}$

As earlier noted, ${ }^{71}$ Chairman Leedom strongly dissented; in his view the record established a prima facie case of improper solicitation. Leedom asserted that by sending the amendment to the Charging Party, his signature was no more than a "ministerial act" since he was literally given no option as to whether he could continue with his original charge without signing the amendment. ${ }^{72}$ Obviously, the Chairman sensed something was amiss where twenty-four Respondents were added to a complaint that started with a simple charge by two men blaming their locals for their being fired. Arguably, however, the Chairman's logic overlooks the eminently practical problems inherent in a situation where discriminatees, unschooled in the protections afforded them under the

68. See, e.g., NLRB v. Homemaker Shops, Inc., 724 F.2d 535 (6th Cir. 1984); NLRB v. Complas Indus., Inc., 714 F.2d 729 (7th Cir. 1983); Hercules Powder Co. v.NLRB, 297 F.2d 424 (5th Cir. 1961); NLRB v. Hopwood, 98 F.2d 97 (2d Cir. 1938).

69. 128 N.L.R.B. 969 (1960).

70. Id. at $972-73$.

71. See supra note 31 and accompanying text.

72. 128 N.L.R.B. at 973. 
Act, go to their local office of the Board to find out if they got a raw deal. The questions about what an investigator should do with information he or she discovers pursuant to the filing of an unfair labor practice charge, or the real alternatives available to a charging party in light of newly discovered evidence, have yet to be answered. The Chairman noted that the Board had never "definitively delineated what conduct by regional personnel constitutes proper advice and handling of an unfair labor practice charge, or at what point proscribed 'solicitation' begins."73

Chairman Leedom's concerns were echoed thirteen years later in a dissent by then-Circuit Judge John Paul Stevens. In NLRB v. Braswell Motor Freight Lines, the Seventh Circuit upheld the Board's actions where the relationship of the allegations in the complaint to those in the charge was questioned by Respondent. ${ }^{74}$ The original charge alleged an unlawful discharge at one of Respondent's terminals. The Board had found unfair labor practices based upon the discharge of employees at three of the Respondent's locations each in different states. The court of appeals found a sufficient nexus among the discharges: the practices complained of all occurred within the same general time period, all dischargees were members of the same union, Respondent's conduct at all three locations was "part of an overall plan to resist organization," and the allegations "were of the same class and character as those set out in the original charge."75 Judge Stevens, in his dissent, noted that "[e]xactly when one alleged unfair labor practice should be considered sufficiently 'related' to another to permit one charge to support two Board complaints-or perhaps I should say, two counts in one complaint-is unclear." He continued:

[I]f all of the allegations involved the same bargaining unit, I would assume that a wide variety of apparently separate transactions could appropriately be included in this single complaint based on a charge filed by a member of that unit. However, if the statutory requirement of a charge is to be meaningful, it does not seem to me that a charge filed by a Chicago local should be sufficient to authorize a nationwide investigation of all layoffs within the recent past. ${ }^{76}$

\section{IV}

\section{Solicitation as an AfFiRmative DefENSE-Short SHRIFT FROM THE BOARD AND THE COURTS}

In the twenty-four years since Petersen was decided, the Board has progressed little toward the delineation its chairman was asking for, nor have the courts offered such further elucidation. Three months after $\mathrm{Pe}$ -

\footnotetext{
73. Id. at 982 .

74. 486 F.2d 743 (7th Cir. 1973).

75. Id. at 746.

76. Id. at 747 .
} 
tersen, an administrative law judge considered in a footnote Respondent's motion to dismiss the allegations "because 1) they were based on a charge solicited by the General Counsel's Representatives, and 2) the amended charge lacks sufficient particularity to support . . . the allegations in the complaint."77 The trial examiner summarily concluded: "As to the first objection, there is no evidence of any improper conduct on the part of the regional office personnel here involved. [Citation to Petersen] The Respondent's second objection is answered by the opinion of the Supreme Court in NLRB v. Fant Milling Company."78

The Board itself considered a charge of solicitation in a footnote in Magic Slacks, Inc. ${ }^{79}$ Although nowhere in the decision are the original and amended charges laid out, the Board dismissed for three brieflystated reasons Respondent's allegations that "the amended charges are invalid because they were prepared by the General Counsel." The Board found that its agent was merely fulfilling his duties, the parties had full opportunity to litigate all the issues raised in the complaint, and the additional charges which assertedly were sponsored by Board personnel involved conduct which, like that in the original charge, interfered with the employees' rights to join or otherwise support the charging union. ${ }^{80}$

Respondents' allegations of solicitation were elevated to more than footnote treatment in The Great Atlantic and Pacific Tea Company. ${ }^{81}$ The Respondents were able to convince the administrative law judge that a Board attorney had solicited the filing of the charge. Testimony by a store manager revealed that the attorney "went into the back room . . . said he needed one signature to a document [later identified as the charge]," and approached an employee, telling him that he was "sort of elected by the store to sign it." The employee later testified that "at the time he signed he did not understand he was initiating unfair labor practice proceedings against his store." 82 Although there were other Charging Parties and charges, the Administrative Law Judge dismissed the part of the complaint initiated by this charge because the prima facie case of solicitation was not rebutted by the General Counsel. The Board modified the findings of the trial examiner, again relegating the discussion of solicitation to a footnote. The Board found it "unnecessary" to decide the issue of improper solicitation because the dismissed case "like others in this consolidated proceeding, related to the legality of the

77. Standard Metal Fabricating Co., 131 N.L.R.B. 844, 852-53 n.13, enforced as modified, 297 F.2d 365 (8th Cir. 1961).

78. Id. at 853 n. 13 .

79. 136 N.L.R.B. 607 (1962), enforcement denied, 314 F.2d 844 (7th Cir. 1963).

80. Id. at 608 n.2.

81. 145 N.L.R.B. 361 (1963), enforced in part, 340 F.2d 690 (2nd Cir. 1965).

82. Id. at 385 . 
lockout. . . ."83

Despite its refusal to find solicitation, the Board, and specifically its administrative law judges before whom hearings of unfair labor practice charges are held, continues to assert that the issue is litigable. For example, in Parisian Bakeries, ${ }^{84}$ Respondents moved for dismissal of the basic charge against them, complaining that it had been solicited by a regional office representative. In November the Charging Party had entered the Board's regional office alleging that the union in which he was only a provisional member had forced his employer to fire him and replace him with a long-time union member and adherent. A complaint was issued in March against the union, charging it with violations of section $8(\mathrm{~b})$. Six weeks later, the same Charging Party filed a second charge alleging that his employer had violated sections 8(a)(1) and (3) by cooperating with the union and terminating him illegally. The administrative law judge wrote: "The relevant case law does plainly reveal this Board's tacit concurrence with the rule of policy that proved 'solicitation' will be considered a valid ground for refusal to proceed with a case." 85 The judge therefore allowed Respondents' attempt to prove solicitation by "close questioning" of the Charging Party regarding his section 8(a)(3) charge, "so belatedly filed," but concluded:

His testimony, which Respondent Company made no effort to vitiate, reveals that his decision to charge the firm with a statutory violation was his own; that his decision in that regard was reached following Respondent Union's motion for a continuance calculated to postpone the Regional Office's originally scheduled hearing date; that he was not, thereafter, counseled to file his second charge by some Regional Office representative. ${ }^{86}$

To some respondents, it would seem incredible that the same "working men who wander helplessly through the maze of labor laws"87 can decide-without expert coaching from regional office personnel-to overcome dilatory tactics on the part of a respondent by adding a second charge and a second charged party.

Five years passed before a respondent again alleged that a Board agent improperly solicited an amendment to a charge. In the next case, ${ }^{88}$ the original charge alleged that the employer violated sections $8(a)(1)$ and (3) by unlawfully discharging one employee and making certain un-

83. Id. at 363 n.3.

84. 169 N.L.R.B. 1047 (1968).

85. Id. at 1057 .

86. Id.

87. For a similar description of workers in the maze of corporate structure, see NLRB v. Houston Distr. Services, 573 F.2d 260, 262-63 (5th Cir.), cert. denied, 439 U.S. 1047 (1978).

88. Nello Pistoresi \& Son, Inc., 203 N.L.R.B. 905 (1973), enforcement denied, 500 F.2d 399 (9th Cir. 1974). 
lawful work assignments. One month later, after amending the charge once, the

NLRB field examiner . . . telephoned the attorneys for Charging Party and pointed out that the amended charge did not include an allegation that Section $8(a)(5)$ was violated, and that in order to allege Section $8(a)(5)$, the charge would have to be amended . . . and that at the end of the last paragraph of the "basis of the charge" should be added the phrase "and have refused to bargain collectively with Teamsters Local 524 , the representative of the employees, with respect to the failure to grant said Christmas bonus." 89

In summary fashion, reminiscent of the earlier statements of his colleagues at the Board's Division of Judges, the trial examiner dealt swiftly-although Respondent may have felt he dealt not at all-with Respondent's charges: "I find that the record fails to establish improper solicitation of the second amended charge."90

Despite the exhortations and incantations about solicitation sounded by the Board and various courts of appeal, none have ever upheld a trial examiner's finding that a Board agent solicited a charge or amendment. For example, in Atlantic and Pacific, a pioneering trial examiner found that Respondents had made a prima facie case of solicitation and recommended dismissal of the charge; the Board rejected his findings and instead considered the underlying unfair labor practice. ${ }^{91}$ In Capitol Fish v. NLRB, the Fifth Circuit, which has more than any other court of appeal considered the issue of solicitation or improper initiation, remanded the case to the Board to consider the issue, where it was ultimately found to be without merit. ${ }^{92}$ And recall that the NLRB trial examiner who felt strongly enough about the actions of the regional office to join the respondent union in seeking to enforce a subpoena served upon the responsible Board agent, did so only to have the effort denied by the Ninth Circuit in Wilmot v. Doyle. ${ }^{93}$

V

\section{Time-BARRED Allegations}

Besides actual solicitation, the second form of solicitation alleged as an affirmative defense by respondents is that the Board has allowed an amendment or complaint based upon illegal acts that occurred more than six months from the date of the initial charge. These allegations of timebarred complaints and amendments are similarly disposed of by the Board in a perfunctory manner.

89. Id. at 909.

90. Id. (citation omitted).

91. 145 N.L.R.B. at 363 n.3. See supra text accompanying notes $40-43$.

92. 140 N.L.R.B. 837 (1963). See supra text accompanying notes 34-39.

93. 403 F.2d 811 (9th Cir. 1968). See supra text accompanying note 49. 
In one example, a charge which alleged that "certain employees" were coerced by their union into paying initiation fees and dues under threat of being discharged from their employment was amended six months later by adding the names of these certain employees; there was a second amendment deleting some of those names. The Board affirmed the finding of the administrative law judge that the amendments were proper since they "merely amplify or particularize the original charge" and are therefore not subject to the statute of limitations. ${ }^{94}$ In another case in which names of alleged discriminatees were added or deleted more than six months after their allegedly illegal terminations, it was held that the charges were not barred by the statute of limitations because an amendment is "timely if it relates to the unfair labor practice inherent in or connected with the original charge" and because all employees were discharged "in the course of the single organizational campaign."95 In yet another case, an administrative law judge denied a motion to dismiss an amendment which added the names of certain employees whom the employer had failed to reinstate after a strike, even though his failure occurred more than six months prior to the date the charge was filed. The judge determined that the refusal to reinstate those other unfair labor practice strikers was "inherently of the same nature and class as Respondent's refusal to reinstate [those originally named in the charge]." "96

Another Charging Party had alleged that a union was guilty of violating section $8(b)(1)(B)$ because the union suspended a member supervisor for crossing a picket line. He amended that charge three months later, alleging the illegal suspension of two more supervisors which had occurred more than six months prior to the date the charge was filed. The administrative law judge rejected Respondent's statute of limitations argument because the charges for all three of the suspensions "rested on the same theory," and because

[The nature of the original charge] was sufficient to inform the union of what was being complained of so [sic] that it is closely related to the violation alleged in the charge and involves neither a drastic departure from the substance of the facts originally charged as to amount to a different case, nor a different type of discrimination resulting from a different union policy not closely related to the charged restraint. . . .97

At least in this case, the judge made some effort to counter any due process arguments Respondents could raise.

94. Local 404, Int'l Bhd. of Teamsters, 100 N.L.R.B. 801 (1952), enforced, 205 F.2d 99 (1st Cir. 1953).

95. Daniel Constr. Co., 244 N.L.R.B. 704, 705 (1979).

96. Harris-Teeter Supermarkets, 242 N.L.R.B. 132, 154 (1979), enforced without opinion, Local 525, Meat, Food and Allied Workers Union v. NLRB, 644 F.2d 39 (D.C. Cir. 1981).

97. New York Newspaper Pressmen's Union, 249 N.L.R.B. 1284, 1289-90 (1980). 
To the contrary, in a recent case, an administrative law judge allowed an amendment to a charge which alleged that four employees were laid off because of their protected concerted activities, adding a fifth "constructive discharge" of an employee who lost his job more than eleven months prior to the amendment. The judge wrote: "I agree with the General Counsel's countering argument that the Board's traditional rule embracing matters that are related to a timely filed charge for purposes of avoiding operation of Section 10(b) obtain here."98

In those cases in which section 10(b) was raised, it is not clear why respondents prevailed in some cases and were ignored in others. Statutes of limitations are, of course, designed to protect defendants from stale charges, to prevent surprise, and to ensure the constitutional right to due process. But some or all of these reasons are frequently ignored when the Board or courts find that consideration of the "whole picture" requires consideration of alleged violations occurring more than six months from the date the charge is filed.

For example, a union filed charges alleging section 8(a)(1) and (3) violations. One year later, after a complaint was issued, the Charging Party alleged violations of section 8(a)(5), including some that occurred more than six months prior to the filing of the original charge. All charges were consolidated into a single complaint. The Respondent had excepted to the Board, alleging that the statute of limitation precluded consideration of any section $8(a)(5)$ violations that occurred more than six months prior to the filing of the second charge. The Board agreed, but it was a pyrrhic victory for the employer. The Board affirmed the order of the administrative law judge, because the remedy ordered for violations of all three sections of the Act would have been the same for violations of only two sections. ${ }^{99}$

The problems facing respondents ultimately lie in proving the charge. In the cases where the issue of solicitation was actually considered, it was generally resolved in favor of the General Counsel because the original charge was found sufficient to support the ultimate complaint as issued-with or without amendments. In the remaining cases, the respondents were unable even to litigate the issue of solicitation because they had no access to the necessary proof-generally the testimony of Board agents. If neither of these factors defeated the solicitation defense, the Board, its administrative law judges, and the courts of appeal generally determined that the salutory end of effectuating the purposes of the Act overrode consideration of the means to that end.

Pity the respondents who raise all three affirmative defenses-solici-

98. Washington Beef Producers, Inc., 264 N.L.R.B. 1163, 1172 (1982).

99. Herald Co., 181 N.L.R.B. 421, $421-22$ (1970), enforced 44 F.2d 430 (2nd Cir.), cert. denied, 404 U.S. 990 (1971). 
tation, consideration of time-barred acts, complaint unrelated to charge - only to be told that their motions will be denied, based upon Kohler or some other oft-cited case. When the Board routinely uses the footnote method of disposal, including rote phrases about a "relationship" to the same or related course of conduct, or protection of the investigative function, or effectuating the purposes of the Act, can respondents take this as a signal that solicitation allegations will not be given serious consideration and thoughtful examination? Do respondents have some right to be fairly investigated by the Board, and can this right be enforced by only occasional examination of the actions of the Board agent, although the respondent has come forward with evidence that the Board agent's investigation was not impartial?

\section{VI \\ Denial of Respondent's Due Process: Complaints Without Clear Basis in a Charge}

As with actual solicitation of the charge or its amendments, and with consideration of time-barred acts, the issuance of a complaint far exceeding the illegality alleged in the charge raises two important issues: the jurisdiction of the Board to act and the protection of the due processes afforded respondents. Although numerous cases have alluded to one or both of these issues, ${ }^{100}$ and a few cases have dealt with the issues at length, ${ }^{101}$ the Board and almost every reviewing court have, in effect, ignored or dismissed them. Such universal disregard to these issues suggests that the Board and the courts agree with Judge Maris, who, forty years ago, decided that the Respondent's allegations that the Board and its agents were guilty of "prejudice and improprieties," were "not advanced on their own merits but rather were devised as a defense to the charges of unfair labor practices as to which no other defense was available." 102 What in other contexts would be meritorious complaints about unfair proceedings or ultra vires exercises of statutory authority are infrequently raised and almost always rejected in Board practice. Despite the limitations found in internal agency operations manuals, or identified in some cases by administrative law judges and reviewing courts, it is apparently common knowledge that, once a charging party enters a regional office complaining, however generally, of conduct violation of the Act, as the Chief Judge of the National Labor Relations Board succinctly concluded, "anything goes."103

100. See, e.g., Red Food Store, 252 N.L.R.B. 116 (1980) (accompanying Administrative Law Judge decision and cases listed therein).

101. E.g., NLRB v. Complas, 714 F.2d 729 (7th Cir. 1983).

102. NLRB v. Weirton Steel Co., 135 F.2d 494, 496 (3rd Cir. 1943).

103. Telephone interview with Melvin Welles, Chief Administrative Law Judge of the National Labor Relations Board (May 13, 1984). 
Constitutional safeguards demand that a respondent be properly apprised of the specifics of its alleged wrongdoing. A thorough discussion of due process is hardly within the scope of this study; however, the elementary requirements of fairness must be a part of any administrative process. The Act itself mandates that a respondent must receive, in due time, a copy of the "complaint stating the charges in that respect. . .."104

The most remarkable feature of the claim of denial of due process under these circumstances is the infrequency with which it is raised. Perhaps respondents understand the dilemma the Board faces in trying to get the "whole picture" without overstepping its bounds. More likely, respondents have given up trying to win on an issue that is so often summarily dismissed. Courts, especially, have always recognized the possibility of inequities when an agency wields its process and power against an individual. Shortly after the Board was established, for example, the Third Circuit denied an employer's charge that Board agents were guilty of improprieties during the investigation stage. Although it found no denial of due process, the court was careful to remind the Board that, even when pursuing justice, it could not run roughshod over a respondent's constitutional guarantees:

Redress for such misconduct upon the part of the Board's prosecuting agents, if it took place, must be provided by the Board in the exercise of its supervisory power over its agents and employees, and not by the courts, unless the misconduct so affected the hearing and decision of the complaints by the Board as to deny the Company due process of law. ${ }^{105}$

It was almost thirty years before a respondent again raised the issue of due process. In The Singer Company, ${ }^{106}$ the Respondent claimed that the rules of the Board required the inclusion in the charge of a clear and concise statement of the facts constituting an unfair labor practice. The administrative law judge responded, in a footnote, that the Board's rules were for its own benefit and not for the benefit of respondents. The judge further opined:

Whether or not, in the prolonged period of investigation which preceded issuance of the final consolidated complaint, Respondent was or was not (and, if not, should have been) given an opportunity to offer its explanations concerning items freshly included in the later consolidated complaint represent questions of fact and policy exclusively of an administrative character not cognizable in unfair labor practice litigation. ${ }^{107}$

The judge did not suggest how Respondents could be afforded a hearing

104. 29 U.S.C. $\$ 160$ (b) (1982) (emphasis added).

105. NLRB v. Weirton Steel Co., 135 F.2d 494, 497 (3rd Cir. 1943).

106. 158 N.L.R.B. 677 (1966).

107. Id. at 680 n.3. 
on these "questions of fact"; he simply chose not to deal with them in his courtroom, and held that the Board, in that case, had the power to issue the complaint it did.

The issue of due process was raised again by the Fifth Circuit when reviewing a cease and desist order issued by the Board in NLRB v. Capitol Fish Company. ${ }^{108}$ At the hearing, Respondents had alleged that the investigating attorney for the Board had improperly solicited "false or twisted statements" from witnesses to corroborate statements made by the Charging Party in support of the complaint. It had been denied permission to put the investigating attorney on the witness stand pursuant to rule 102.118, which precludes a Board attorney from testifying without permission of the General Counsel. ${ }^{109}$ The Fifth Circuit noted Respondent's contention that it had been denied the right to interrogate the attorney in violation of the due process clause of the fifth amendment. ${ }^{110}$ Although the court agreed with the Respondent that it should have had the right to examine the attorney, it concluded: "We find it unnecessary, however, to reach the constitutional issue; exclusion of the investigating attorney as a witness violated the statutory provisions governing proceedings under the Act." ${ }^{111}$ The court remanded the case to the Board, ordering that the attorney be allowed to testify, subject to cross-examination by Respondent. ${ }^{12}$

In a post-hearing brief to the Board, the Respondent in Hiatt General, Inc. ${ }^{113}$ protested the action by an administrative law judge allowing the General Counsel to amend a complaint at the hearing, because "insofar as it alleges specific Section 8(a)(1) conduct, [the amendment] departs so drastically from the original charge, complaint, and amended complaint [which alleged only derivative 8(a)(1) violations] that Respondent was denied due process." 114 The Board, upon reviewing the decision in favor of the Charging Party by the administrative law judge, found no merit in Respondent's claim. According to the Board: "We note that counsel for the General Counsel apprised Respondent's counsel of the specific amendments to the complaint several days prior to the hearing, and that the protagonist of the $8(a)(1)$ violations was present and testified at the hearing after the amendments and relevant employee testimony." 115 The Board gave no explanation why the presence of the alleged wrongdoer and the privilege of giving his own testimony were

108. 294 F.2d 868 (5th Cir. 1961).

109. 29 C.F.R. $\S 102.118$ (1984).

110. 294 F.2d 868, 869 (5th Cir. 1961).

111. Id. at $869-70$.

112. 140 N.L.R.B. 837 (1963) (where the Board found the same result as earlier, despite the testimony of the Board attorney.)

113. 257 N.L.R.B. 960 (1981), enforced without op., 685 F.2d 444 (9th Cir. 1983).

114. Id. at 960 n.1.

115. Id. 
sufficient to guarantee Respondent due process. More than likely, the Board felt an explanation was unnecessary, since the due process argument had rarely been raised against the Board, and when it had, it was almost always found wanting.

In another case, an especially conscientious administrative law judge himself raised the issue of Respondent's due process rights and found, in a footnote, that they had been protected, even though the judge had allowed General Counsel to amend the complaint at the hearing. ${ }^{116}$ The original complaint alleged that the employer violated section 8(a)(5) by refusing to bargain with the International Brotherhood of Teamsters, a union that represented the company's drivers. The General Counsel sought to amend by adding an allegation of a violation of section 8(a)(2), because facts established that the employer had suggested to its drivers that they join the United Brick and Clay Workers of America, a union which represented the company's other employees. The administrative law judge granted the motion, emphasizing that a representative for the Brick and Clay Workers union had written the Board's regional director prior to the hearing, stating that if the employer were forced to bargain with the Teamsters, then his union would disclaim all interest in the drivers. The judge found that:

[By this letter, the representative] voluntarily subordinated the standing of his Brick and Clay Workers to disposition of this proceeding. In so doing he provided a necessary due-process foundation to the amended characteristic of the complaint, by which the General Counsel sought to establish an 8(a)(2) violation. ${ }^{117}$

In another case, the Respondent raised a unique affirmative defense. The charge, originally filed by an employee against a union, was amended to include charges against the employer after the Board began its investigation. The Respondent employer moved to dismiss the com-

116. American Pac. Concrete Pipe, 262 N.L.R.B. 1223, 1232 n.6 (1982), enforced without op., 709 F.2d 1514 (9th Cir. 1983), supp. op., 271 N.L.R.B. No. 150 (1984).

117. Id. In two recent cases, courts of appeal found a denial of a respondent's due process, reasoning that amendments to complaints cannot be made if respondent will be denied a "meaningful opportunity to meet the complaint." In each case, it was the respondent's lack of notice, rather than the substance of the claim, that offended the court. In NLRB v. Complas, 714 F.2d 729 (7th Cir. 1983), the administrative law judge had allowed the General Counsel to amend an original complaint, which alleged only the illegal discharge of an employee, to include claims of unlawful interrogation of other employees about union activities. The court held that the amendment should not have been allowed because the amendment was made during the course of a one-day hearing, the Respondent repeatedly objected to the amendment, and an adjournment was denied the Respondent. The court found that the subject matter of the amendment was a proper outgrowth of the investigation and that it was appropriately related to the original charge; it was the procedure of amending at the hearing that violated the Respondent's due process right. In NLRB v. Homemaker Shops, Inc., 724 F.2d 535 (6th Cir. 1984), the court held that an amendment to a complaint that was "similar in nature to the allegation" in the original complaint and "occurred at roughly the same time" denied Respondent due process because Respondent had been apprised of the amendment only three days prior to the date set for the hearing on the unfair labor practice. 
plaint because, as proof of the charge against the employer, the Board used statements and affidavits gathered from the employer during the investigation of the employee's allegations against the union. ${ }^{118}$ The Respondent employer argued that this behavior "smacks of constitutionally proscribed entrapment, since Respondent Company presently stands charged on the basis of data innocently provided, with respect to Respondent Union's collateral matter, pursuant to representations [by the Board agent] that Respondent Company would not be legally 'affected' thereby."119 The judge noted that entrapment would require the Respondent to prove that it was persuaded to participate in illegal activity by a Board agent. That, of course, was not the problem. Secondly, the judge was satisfied that the Board agent had no reason to believe, at the time he took statements from the Respondent's employee, that the company would ultimately be charged with violations of labor laws. ${ }^{120}$ Therefore, this "innocently" gathered evidence provided guilelessly by the employer, could later be used against that same employer, without violating its rights.

Respondents have been only slightly more successful in their claims that a charge does not support a complaint or amendment than they have been in their claims that Board agents solicited a charge, complaint, or amendment. In both cases the reasons given by administrative law judges and the reviewing Board and courts for supporting amended charges or complaints appear frequently to be insubstantial, undocumented, and rotely listed. To respondents' dismay, their defenses are often casually dismissed by citations to the very cases which established that solicitation and unfounded variance among charges, complaints, and amendments violate the spirit if not the letter of the law. And, as earlier seen, consideration of the due process rights of a respondent in a Board matter, especially a guilty respondent, is almost never given.

A recent example is a case involving union organization of the employees at a rest home. ${ }^{121}$ Even though the union had alleged only violations of section 8(a)(3), the administrative law judge found violations of section 8(a)(1) as well, because evidence adduced at the hearing established that the Respondent had engaged in illegal interrogation of one of the discharged employees. In response to the employer's protest that the complaint could not be amended to include section $8(a)(1)$ violations, the judge noted that:

The complaint need not be restricted to the precise allegations of the charge. So long as there is a timely charge the complaint may allege any matter closely related to or growing out of the charged conduct, or re-

118. Parisian Bakeries, 169 N.L.R.B. 1047 (1968).

119. Id. at 1057.

120. Id. at 1058 .

121. Danmor Co., 260 N.L.R.B. 816 (1982). 
lated to the controversy which produced the charge, or which relates back to or defines the charge more precisely. ${ }^{122}$

In another case, a charge alleging discrimination against union employees and a refusal to bargain in violation of sections 8(a)(1), (3) and (5) gave rise to a complaint which was amended at the hearing to allege unlawful interrogation and unlawful support of an antiunion petition. ${ }^{123}$ The administrative law judge rejected Respondent's protestations regarding the amendments, reasoning that the added allegations were "clearly related to the acts alleged in [the original] charges and grow out of the same proceeding." He also found a "sufficient nexus between the allegations in the charge and those set forth in the complaint," and therefore concluded that it was "immaterial that the violations alleged in the complaint occurred after the filing of the charge." 124

In a later case, the charge alleged, only generally, that the employer had refused to bargain with a local union. The Board and the trial examiner agreed that this charge could support an amendment to the complaint alleging that the employer's failure to comply with seniority and recall provisions and its failure to notify the union of a recall-both of which occurred prior to the filing of the charge-violated sections 8(a)(1) and (5). The judge wrote:

Although this [first] charge does not specifically refer to the events surrounding the recall as violations, it is sufficiently broad to support the complaint. . . . The specific allegations of $8(a)(5)$ violations which are the subject of Responent's motion [to dismiss] are clearly related to the more general 8(a)(5) allegations contained in the timely filed charge. ${ }^{125}$

In yet another case, a charge that the employer was guilty of disparate enforcement of company rules and unlawful harassment in violation of sections $8(a)(1)$ and (3) was found to be "sufficiently broad to form a proper nexus" with allegations in the complaint that the employer confiscated and destroyed union organizational material. ${ }^{126}$

In several cases, the hearing officer relied on the catch-all boilerplate language on forms signed by a charging party that "by these and other acts" respondent has violated the National Labor Relations Act. ${ }^{127}$ For example, a charge alleging that an employer violated sections 8(a)(1) and (5) by failing to bargain in good faith supported a complaint that alleged the employer withheld wage increases from union members which it had granted to other employees-an action that occurred more

122. Id. at 823 (footnote omitted).

123. Holland Am. Wafer Co., 260 N.L.R.B. 267 (1982).

124. Id. at $273 \mathrm{n} .15$.

125. Flex Plastics, Inc., 262 N.L.R.B. 651, 652 (1982), aff'd per curiam, 726 F.2d 272 (6th Cir. 1984).

126. Materials Research Corp., 246 N.L.R.B. 398, 404 (1979).

127. See, e.g., Holland Am. Wafer Co., 260 N.L.R.B. 267, 273 n.15 (1982); Keystone-Seneca Wire Cloth Co., 244 N.L.R.B. 398, 398-99 (1979). 
than six months from the time of the filing of the original charge. The judge relied on boiler-plate language and determined that the refusal to grant wage increase was "part and parcel of the unfair labor practices originally charged." 128 In a similar case, the administrative law judge found that the catch-all language was "sufficient to warrant the inclusion of any Section 8(a)(1) allegation in the complaint."129 The judge allowed an amendment that changed the employer's alleged motivation for discharge of an employee from discharge due to union activity to discharge due to protected concerted activity. According to the judge, in addition to the catch-all language "the allegation as pleaded in the complaint was inherent in, or connected with, the original charge." 130

Examination of those few cases in which the Board found that there was not a proper relationship between a charge and a complaint or between a complaint and an amendment affords few insights into how one can determine when there is improper solicitation or initiation of either. For example, a Charging Party who was employed by a company that had been bought out by another company brought charges against both of these employers. The Charging Party alleged that he was the only employee from the first company who had not been hired by the second company because he was the only non-union employee. ${ }^{131}$ The Charging Party also filed a section 8 (b) charge against the union. The Board found that there was insufficient evidence to support the charge against the union. ${ }^{132}$

In another case, the Board found that the administrative law judge had erred in granting the General Counsel's motion to amend the original complaint to add an allegation that Respondent had violated section $8(a)(5)$. The original complaint had alleged only violations of section 8(a)(1) and (3) based on the employer's discharge of an employee for engaging in union and other protected activities. The Board opined:

The last-minute amendment alleged that Respondent violated Section

8(a)(5) by refusing to make benefit payments for [the Charging Party] during his employment as an apprentice carpenter. The facts surrounding this amendment are not related to the facts surrounding the allegations in the original charge. Thus, the original charge did not apprise Respondent of the factual matter upon which the amendment to the complaint was predicated . . . [T] he amendment to the complaint was not "closely related to the violations alleged in the charge" . . . . ${ }^{133}$

In yet another case, an administrative law judge denied an amend-

128. South Shore Hosp., 256 N.L.R.B. 1, 8-9, n.22 (1981).

129. Keystone-Seneca, 244 N.L.R.B. at 399. Accord The Singer Co., 158 N.L.R.B. 677, 680-82

(1966).

130. Keystone-Seneca, 244 N.L.R.B. at 399 (footnote omitted).

131. Swier Electric Co., 223 N.L.R.B. 569 (1976).

132. Id. at 572.

133. R.J. Causey Constr. Co., 241 N.L.R.B. 1096, 1096-97 (1979) (footnote omitted). 
ment to include a charge that employer had violated section 8(a)(3). Although the judge found violations of sections 8(a)(1) and (2) on the same facts, the General Counsel excepted. The Board refused to pass on the issue of the judge's refusal to allow the amendment, since the award would have been the same with or without a finding of an 8(a)(3) violation. ${ }^{134}$

Although some early cases held that the Board's complaint must be limited to the specific allegations of the charge, it was noted in Kohler that in later cases "the courts then began to interpret Section 10(b) as requiring something less than exact similarity between charge and complaint."135 Red Food Store, for example, presented the question whether a claim of an illegal discharge of a grocery store clerk, which was dismissed by the Regional Director, could support a complaint which alleged only violations of section $8(a)(1)$ by the store manager against employees of another company who drove delivery trucks to the store. ${ }^{136}$ Referring to the Kohler case, the judge found that "[t]he problem of constructing a standard which describes the permissible 'something less'but not too much less-than 'exact similarity between charge and complaint' has not been easy to resolve." 137 The judge dismissed the section 8(a)(1) complaint as to the drivers because the complaint contravened the directives in Fant Milling that the Board not "expand the charge as it pleased." The judge reasoned:

This conclusion may be deemed to rest on a technicality, but it is a technicality imbedded in the statute which expresses the will of Congress. In a statute thorny with technicalities, upon which both employers and unions are sometimes impaled, technical dispositions are not a rarity. ${ }^{138}$

This judge apparently gleaned a prohibition against solicitation from the sponsors of the Act. There is something not quite right about what the Board and its agents occasionally, if judged by case law, or frequently, if judged by practical realities, do. He reviewed many of the cases in which respondents decried the absence of a properly grounded complaint or amendment, and found that the decisions used such standards as " 'closely related,' 'some relationship,' 'close enough to negate the possibility that the Board is proceeding on its own initiative,' [and] 'a part of the controversy,' " to help determine whether a motion to dismiss should be granted. ${ }^{139}$ In a futile effort to provide some explication, the Fifth Circuit "explained" that: "[t]he requirement of a sufficient relationship between the charge and the complaint does not necessarily mean

134. Type Rite Ribbon Mfg., 264 N.L.R.B. 650, 650 n.2 (1982).

135. N.L.R.B. v. Kohler Co., 220 F.2d 3, 6 (7th Cir. 1955).

136. Red Food Store, 252 N.L.R.B. 116 (1980).

137. Id. at 119 .

138. Id. at 123 .

139. Id. at 120 . 
a 'close' relationship; 'the relationship need be close enough only to negate the possibility that the Board is proceeding on its own initiative rather than pursuant to a change." "140 No salient test seems to have emerged. Defenders may point out that many areas of the law require examination on a case-by-case basis, to see when and whether a violation occurred. But in these circumstances, in almost every case, there has been neither a careful analysis nor a finding of any violation.

An obvious starting point for a test is provided by the dissenting comments of then-Circuit Judge Stevens in NLRB v. Braswell Motor Freight Lines. ${ }^{141}$ Stevens found something wrong when allegations by one local concerning activity at a particular plant spawned a nationwide investigation of all the company's layoffs "within the recent past."142

This proposed test would not limit the Board's scope of investigation. The Board must investigate thoroughly in order to understand the parties' actions properly and to set the facts in their environment. But license to uncover the facts should not be coterminous with authority to act on every fact which might form an allegation in a pleading. The Act does have a time-bar, and the Board should respect it. Actions outside the section $10(\mathrm{~b})$ period should be used as background, not as separate allegations.

It is more difficult to place a limit on the type of activity which can be sufficiently grounded on a given charge. Then-Judge Stevens suggested a geographical limit, implying that a charge concerning a strictly "local" issue cannot support a nationwide investigation. However, geographic scope has not been an issue in the solicitation cases reviewed above. At the very least, if an original charge is dismissed, then other charges based upon unalleged conduct discovered during an investigation of the original charge should also be dismissed. In addition, the limits on the type of activity grounded on a charge could start with the different "clusters" of activity suggested by the paragraphs of the Act itself. Thus, a section $8(a)(3)$ charge could not support a section $8(a)(2)$ complaint, whether or not they took place in the same "course of conduct." Antiunion discrimination against a specific individual is not necessarily the sort of conduct present when improper assistance is given to a labor organization. The parties may be the same, the motivations may be identical, but two different legal rights are at stake. This is not to say, however, that a section $8(a)(5)$ charge could not, with certain facts, support a section $8(a)(2)$ complaint. For example, refusal to bargain with a lawful representative can be an element in encouraging the formation of a

140. N.L.R.B. v. Rex Disposables, 494 F.2d 588, 590 (5th Cir. 1974) (quoting N.L.R.B. v. Central Power and Light Co., 425 F.2d 1318, 1321 n.3 (5th Cir. 1970)).

141. 486 F.2d 743, 746-48 (7th Cir. 1973).

142. Id. at 747 . 
rival representative. My point is, that certain kinds of allegations and activities properly lead to issuance of certain unfair labor practice complaints; it is plain that others, untimely or unrelated factually, do not.

\section{CONCLUSION}

Respondents can continue to make such affirmative defenses as initiation and solicitation whenever it appears practical. The likely results, however, are that no merit will be found in such defenses. The sufficiency of the charge, the ultimate guilt of the respondents, or rule 102.118 defeat the defense of solicitation or initiation. In addition, the Board has determined that such affirmative defenses are insignificant because the salutary purposes of the Act are effectuated by the issuance of the complaint followed by a full and fair hearing of the unfair labor practice charge. Moreover, the Supreme Court has given the Board considerable leeway "in order properly to discharge the duty of protecting public rights which Congress has imposed upon it."143

Although the Act has been amended to better balance its reach, this policy has not changed. If an unfair labor practice is fairly tried and proved, little attention is paid to the details of its origin. Certainly, a Board agent cannot be a charging party, but there are precious few other circumstances in which improper solicitation or initiation will be found. Arguably, this runs counter to the articulated limit on the power of the Board, which is that it may seek out violations of the Act only upon receipt of a charge. But the practicalities of the enforcement of the Act require a less than passive clerical role for Board agents in the filing of unfair labor practice charges and related amendments and complaints. And written directives mandate an active role for Board agents in the processes of filing amendments.

The courts are unwilling to deny enforcement of an order they determine was issued in response to a proven violation. ${ }^{144}$ Perhaps solicitation and initiation should not even be issues. The Board certainly does not roam the streets looking for secondary boycotts, nor does it frequent union halls to find out about discriminatory discharges. But the problem of solicitation is inherent in the system in which the barest allegation, if facially valid, generates a full-scale investigation by Board employees trained in the nuances of violative conduct. The system also expects these employees not only to conduct "impartial" investigations, but also to prosecute the case if merit is found in the charge. The line between

143. Fant Milling v. NLRB, 360 U.S. 301, 308 (1959).

144. A possible course of action is of course, a $\S 1983$ suit against the particular agent or agents suspected of solicitation. 42 U.S.C. $\S 1983$ (1982). This is, of course, beyond the purview of this paper. It is, however, an alternative to raising the issue to the Board itself or asking a reviewing court to deny enforcement of an order that is based upon a meritorious though procedurally irregular charge. 
impartial fact-gathering and adversarial case file preparation becomes blurred sometime during each meritorious case. The valid suspicions of respondents, and even of Board personnel, that agents have overstepped their bounds are difficult to prove and, thus far, impossible to sustain when objection is made before the Board or reviewing courts. 